\title{
PENGARUH TEKNIK BRAINWRITING TERHADAP KETERAMPILAN MENULIS TEKS DESKRIPSI SISWA KELAS VII SMP NEGERI 1 CARINGIN KABUPATEN SUKABUMI
}

\author{
HENTI ROHENTI \\ heroti2010@gmail.com \\ Univestitas Muhammadiyah Sukabumi
}

\begin{abstract}
Abstrak. Penelitian ini dilatarbelakangi oleh rendahnya kemampuan dan minat siswa dalam menulis teks deskripsi. Adapun tujuan penelitian ini adalah untuk mengetahui kemampuan menulis teks deskripsi siswa kelas VII SMP Negeri 1 Caringin sebelum menggunakan teknik brainwriting, mengetahui kemampuan menulis teks deskripsi siswa kelas VII SMP Negeri 1 Caringin setelah menggunakan teknik brainwriting, dan mengetahui pengaruh teknik brainwriting terhadap keterampilan menulis teks deskripsi siswa kelas VII SMP Negeri 1 Caringin. Penelitian ini merupakan penelitian kuantitatif dengan menggunakan metode PreExperimental Design dengan Desain penelitian One-Group Pretest-Postest Design. Sampel pada penelitian ini berjumlah 30 orang. Hasil penelitian ini adalah pertama kemampuan siswa Kelas VII SMP Negeri 1 Caringin dalam menulis teks deskripsi sebelum menggunakan teknik brainwriting dengan nilai rata-rata 47,83 dalam kategori kurang (70\%). Kedua, kemampuan siswa Kelas VII SMP Negeri 1 Caringin dalam menulis teks deskripsi setelah menggunakan teknik brainwriting dengan nilai rata-rata 79,00, dalam kategori baik (90\%). Ketiga, terdapat pengaruh yang signifikan dengan menggunakan teknik brainwriting dalam meningkatkan keterampilan menulis teks deskripsi siswa kelas VII SMP Negeri 1 Caringin. Hasil yang diperoleh dari penelitian berdasarkan hasil perhitungan statistik nilai $t_{\text {hitung }}$ $(17,581)>t_{\text {tabel }}(2,045)$ menunjukkan hipotesis nol ditolak dan hipotesis alternatif diterima.
\end{abstract}

Kata Kunci: pengaruh, teknik brainwriting, teks deskripsi

Abstract. This research was motivated by the low ability and interest of students in writing descriptive texts. The purpose of this study was to determine the ability to write descriptive text of seventh grade students of SMP Negeri 1 Caringin before using brainwriting techniques, to determine the ability to write descriptive text for seventh grade students of SMP Negeri 1 Caringin after using brainwriting techniques, and to determine the effect of brainwriting techniques on writing descriptive text skills VII grade students of SMP Negeri 1 Caringin. This research is a quantitative study using the Pre-Experimental Design method with the One-Group Pretest-Postest Design research design. The sample in this study amounted to 30 people. The results of this study were the first grade VII students' ability of SMP Negeri 1 Caringin in writing descriptive texts before using the brainwriting technique with an average score of 47.83, in the poor category (70\%). Second, the ability of Class VII students of SMP Negeri 1 Caringin in writing descriptive texts after using brainwriting techniques with an average score of 79.00, in good category (90\%). Third, there is a significant influence using brainwriting techniques in improving the writing skills of seventh grade students of SMP Negeri 1 Caringin. The results obtained from research based on the results of statistical calculations of the value of $t$ count (17.581)> table (2.045) maked the null hypothesis rejected and the alternative hypothesis accepted.. Keywords: influence, brainwriting technique, description text

\section{PENDAHULUAN}

Bahasa Indonesia adalah salah satu mata ajar yang wajib diajarkan kepada siswa di lembaga pendidikan formal, baik jenjang pendidikan dasar, menengah bahkan sampai universitas. Dalam kurikulum 2013, pembelajaran Bahasa Indonesia sudah berbasis teks. Setiap siswa mempelajari berbagai jenis teks sehingga keterampilan berbahasa seperti menyimak, membaca, berbicara dan menulis terintegrasi dalam setiap jenis teks.

Menulis merupakan keterampilan berbahasa yang bersifat produktif. Aktivitas memproduksi tulisan bukan hanya sekedar menyalin kata-kata atau kalimat tetapi menuangkan ide/gagasan, pendapat dalam bentuk tulisan sehingga mudah ditangkap 


\section{HENTI ROHENTI \\ PENGARUH TEKNIK BRAINWRITING TERHADAP KETERAMPILAN MENULIS TEKS DESKRIPSI SISWA KELAS VII SMP NEGERI 1 CARINGIN KABUPATEN SUKABUMI}

oleh pembaca. Sebagaimana yang diungkapkan oleh Chaer (2014 : 49), bahasa itu dikatakan produktif, artinya meskipun unsur-unsur bahasa itu terbatas, tetapi dengan unsur-unsur yang jumlahnya terbatas itu dapat dibuat satuan-satuan bahasa yang jumlahnya tidak terbatas, meski relatif, sesuai dengan sistem yang berlaku dalam bahasa itu." Berdasarkan pendapat tersebut, bahasa bersifat produktif artinya dari unsur-unsur bahasa yang terbatas dapat menghasilkan kalimat, teks bahkan karya tulis yang tidak terbatas.

Kegiatan menulis tidak banyak disukai oleh siswa karena menulis dipandang sebagai kegiatan yang paling rumit diantara keterampilan berbahasa lainnya. Sering kali siswa mengalami kesulitan dalam menuangkan dan mengekspresikan ide, gagasan, pikiran ke dalam bentuk karya tulis bahkan mengawali kalimat pertama pun masih kesulitan. Hal inilah yang menjadi tantangan penulis untuk membawa siswa berhasil menciptakan sebuah tulisan yang utuh.

Berdasarkan Permendikbud No. 37 tahun 2018, Teks deskripsi merupakan salah satu jenis teks yang diajarkan di Sekolah Menengah Pertama (SMP)/MTs yang dapat melatih siswa menggambarkan objek secara rinci dan merangsang kreativitas siswa dalam mengolah kata sehingga pembaca seolah-olah melihat, mendengar, dan merasakan apa yang digambarkan dalam tulisan. Dalam pembelajaran teks deskripsi ini diharapkan siswa mampu mengungkapkan gagasan, pikiran dalam bentuk teks deskripsi sesuai dengan struktur teks dan kebahasaan teks deskripsi. Sebagaimana yang diungkapkan oleh Kosasih dan Kurniawan (2018: 16) bahwa:

“ Menulis teks deskripsi berarti menggambarkan suatu objek atau keadaan tertentu dengan serinci-rincinya berdasarkan sudut pandang pribadi penulisnya, bertujuan untuk menggambarkan suatu objek sehingga pembacanya seolah-olah menyaksikan dan merasakan langsung suatu objek dengan sejelas-jelasnya atau secara terperinci”.

Berdasarkan hasil wawancara dengan salah satu guru mata pelajaran Bahasa Indonesia di SMP Negeri 1 Caringin dan beberapa siswa kelas VII, ada beberapa permasalahan dalam pembelajaran menulis teks deskripsi yaitu sebagai berikut. Pertama, masih rendahnya nilai siswa dalam menulis teks deskripsi. Lebih dari $50 \%$ nilai menulis teks deskripsi siswa masih kurang dari batasan nilai ketuntasan minimal yaitu 75 untuk kelas VII. Rendahnya nilai siswa disebabkan oleh rendahnya pemahaman materi menulis teks deskripsi. Kedua, dalam menulis deskripsi umum dan deskripsi bagian masih banyak ditemukan yang tidak sesuai dengan konsep deskripsi umum dan deskripsi bagian. Pemahaman siswa mengenai struktur teks deskripsi masih kurang. Ketiga siswa kurang berminat dan tidak termotivasi dalam menulis teks deskripsi. Hal ini disebabkan oleh menulis teks deskripsi itu sulit. Kesulitan dalam menulis teks deskripsi disebabkan oleh siswa belum terbiasa untuk menulis sehingga siswa kesulitan dalam menuangkan idenya dan merangkainya menjadi jalinan kalimat untuk membentuk tulisan sehingga tulisannya dapat dipahami oleh orang lain.

Untuk mengatasi masalah ini sebaiknya guru menggunakan teknik pembelajaran yang lebih membangun kreativitas siswa sehingga pembelajaran menulis teks deskripsi dapat dicapai sesuai dengan tujuan pembelajaran.

Guru harus mampu memilih strategi atau teknik pembelajaran yang dapat membuat siswa lebih aktif, kreatif dan inovatif sehingga dapat mencapai tujuan pembelajaran. Salah satu teknik yang digunakan adalah brainwriting.

Brokop dan Bill Persal (2009:9) yang menyatakan bahwa brainwriting merupakan cara yang memungkinkan bagi setiap individu untuk berbagi ide yang ditulis di atas kertas. Lebih lanjut Paulus dan Nijstad (2003:129) mengemukakan bahwa brainwriting dapat dijadikan sebagai alternatif dalam mencurahkan ide atau pendapat secara tertulis. Dengan menggunakan teknik brainwriting ini, diharapkan dapat mempermudah dan mempercepat pemahaman siswa dalam menulis teks deskripsi. Paulus dan Nijstad (2003:129) menjelaskan bahwa brainwriting dilakukan untuk menghasilkan gagasan yang beraneka ragam tentang suatu hal atau topik tertentu.

Brainwriting bertujuan untuk membentuk atau menumbuhkan ide-ide tertulis. Ada beberapa siswa yang terkadang tidak dapat menyampaikan idenya secara lisan. Oleh karena itu, dengan adanya brainwriting dapat membantu siswa yang mengalami kendala dalam mengungkapkan idenya secara lisan. Teknik brainwriting merupakan salah satu teknik yang dapat diterapkan dalam keterampilan menulis salah satunya yaitu keterampilan menulis teks deskripsi.

Langkah-langkahTeknik Brainwriting menurut Damai, et. al (2017:37), langkahlangkah teknik brainwriting adalah sebagai berikut. Pertama, siswa dan guru mendiskusikan tema tulisan. Kedua, siswa diberi kesempatan untuk melakukan proses prapenulisan secara individu atau kelompok, 


\section{HENTI ROHENTI \\ PENGARUH TEKNIK BRAINWRITING TERHADAP KETERAMPILAN MENULIS \\ TEKS DESKRIPSI SISWA KELAS VII \\ SMP NEGERI 1 CARINGIN KABUPATEN SUKABUMI}

baik indoor maupun outdoor. Jika berkelompok, hal-hal yang dibicarakan(diskusi) dan berbagai saran teman harus dituangkan dalam kartu/lembar gagasan. temuan siswa dalam kegiatan prapenulisan dituangkan dalam lembar/kartu gagasan. Ketiga, siswa diberi kesempatan untuk menulis secara mandiri. Keempat, setelah menulis draft, teks deskripsi siswa ditukarkan dengan siswa lain, berpasangan/acak dan mereka melakukan tahap pasca menulis. Siswa melakukan brainwriting dalam menyunting teks deskripsi teman lainnya. Kelima, siswa diminta memberikan saran, komentar, gagasan dan semacamnya atas tulisan teman yang dibacanya secara tertulis dalam lembar/ kartu gagasan. Keenam, setelah teks deskripsi dikembalikan beserta kartu gagasan, siswa memperbaiki teks deskripsinya kembali. Ketujuh, beberapa siswa diminta menyajikan teks deskripsi secara lisan. Kedelapan, guru dan siswa lain merefleksi (menanggapi dan mengevaluasi) teks deskripsi teman yang disajikan. Kesembilan, tulisan siswa dikumpulkan dan dievaluasi oleh guru.

Berdasarkan masalah tersebut, penelitian ini bertujuan sebagai berikut. Pertama mengetahui keterampilan menulis teks deskripsi siswa kelas VII SMP Negeri 1 Caringin sebelum teknik pembelajaran brainwriting. Kedua, mengetahui keterampilan menulis teks deskripsi siswa kelas VII SMP Negeri 1 Caringin dengan teknik pembelajaran brainwriting. Ketiga, mengetahui pengaruh penggunaan teknik brainwriting terhadap keterampilan menulis teks deskripsi pada siswa kelas VII SMP Negeri 1 Caringin

\section{METODE PENELITIAN}

Metode yang digunakan pada penelitian ini adalah metode penelitian kuantitatif karena data metode ini berupa angka-angka dan analisis menggunakan statistik. Sebagaimana yang dikemukakan Sugiyono (2017:8) bahwa metode penelitian kuantitatif dapat diartikan sebagai metode penelitian yang berlandaskan pada filsafat positivisme, digunakan untuk meneliti pada populasi atau sampel tertentu, pengumpulan data menggunakan instrumen penelitian, analisis data bersifat kuantitatif/statistik, dengan tujuan untuk menguji hipotesis yang telah ditetapkan.

Populasi penelitian ini adalah siswa kelas VII pada SMP Negeri 1 Caringin tahun ajaran 2019/2020, dengan jumlah populasi sebanyak 118 orang siswa. Penelitian ini menggunakan teknik Purposive Sampling yaitu teknik mengambil sampel dengan tidak berdasarkan random, daerah atau strata, melainkan berdasarkan atas adanya pertimbangan yang berfokus pada tujuan tertentu (Arikunto, 2014). Teknik purposive sampling pada dasarnya dilakukan sebagai suatu teknik yang secara sengaja mengambil sampel tertentu yang telah sesuai dan memenuhi segala persyaratan yang dibutuhkan meliputi: sifat, karakteristik, ciri dan kriteria sampel tertentu, dalam hal ini pengambilan sampel juga harus represantatif dari populasi. Sampel yang tidak memenuhi kriteria akan berdampak buruk pada hasil penelitian yang dilakukan karena dalam suatu penelitian diperlukan sesuatu yang merupakan cerminan utuh dari suatu populasi yang akan diteliti. Sampel yang dipilih adalah kelas VII-D dengan jumlah siswa 30 orang.

Menurut Sugiyono (2017:102) instrumen penelitian adalah suatu alat yang digunakan untuk mengukur fenomena alam maupun sosial yang diamati. Instrumen penelitian merupakan alat ukur yang digunakan dalam pengumpulan data. Instrumen pada penelitian ini alat untuk mengukur kemampuan siswa dalam menulis teks deskripsi berupa tes, baik tes awal (pretest) maupun tes akhir (posttest).

Tes dilakukan dengan memberikan esai kepada siswa. Contoh soal yang digunakan dalam tes:'Tulislah sebuah teks deskripsi dengan tema lingkungan tempat tinggalmu." Perintah soal untuk tes awal (pretest) dan tes akhir (posttest) sama. Tes tersebut menggunakan pedoman penilaian menulis teks deskripsi yang meliputi aspek judul, identifikasi, deskripsi, penutup dan penggunaan bahasa.

Langkah-langkah dalam teknik analisis data penelitian ini sebagai berikut., membaca dan memeriksa karangan Pertama deskripsi siswa sesuai dengan rubrik penilaian menulis teks deskripsi; Kedua menentukan skor dan mengonversi skor menjadi nilai keterampilan menulis teks deskripsi; Ketiga, mengolah data nilai menulis teks deskripsi dengan menentukan nilai tertinggi, nilai terendah, nilai rata-rata. Keempat mengelompokkan nilai menulis ke dalam kategori kurang, cukup, baik dan sangat baik. Kelima, melakukan uji normalitas dan uji hipotesis dengan teknik uji-t untuk menguji perbedaan antara rataan nilai tes awal dan tes akhir terdapat perbedaan atau tidak. Jika $t_{\text {hitung }}>t_{\text {tabel }}$, hipotesis diterima, dan jika Jika $t_{\text {hitung }}<\mathrm{t}_{\text {tabel, }}$, hipotesis tidak diterima. Keenam, membahas hasil analisis data dan menyimpulkan hasil pembahasan. 


\section{HENTI ROHENTI}

PENGARUH TEKNIK BRAINWRITING TERHADAP KETERAMPILAN MENULIS TEKS DESKRIPSI SISWA KELAS VII

SMP NEGERI 1 CARINGIN KABUPATEN SUKABUMI

HASIL DAN PEMBAHASAN

1. Hasil Penelitian

1. Keterampilan Siswa Menulis Teks Deskripsi Sebelum Menggunakan Teknik Brainwriting

Sebelum siswa diberi perlakuan berupa pembelajaran menulis teks deskripsi dengan menggunakan teknik brainwriting, terlebih dahulu dilakukan pretest. Tes ini dilakukan untuk mengetahui keterampilan awal menulis teks deskripsi siswa kelas VII SMP Negeri 1 Caringin. Data lengkap nilai pretes keterampilan siswa menulis teks deskripsi sebagai berikut. Pertama lima orang siswa yang mendapatkan nilai antara 30 sampai dengan 35 dengan persentase 16,7\%. Kedua tujuh orang siswa mendapatkan nilai antara 36 sampai 41 dengan persentase $23,3 \%$. Ketiga tidak ada siswa yang mendapatkan nilai antara 42 sampai $47(0 \%)$. Keempat, enam orang siswa mendapat nilai pretes antara 48 sampai 53 dengan persentase 20\%. Kelima, tujuh siswa yang mendapatkan nilai antara 54 sampai dengan 59 dengan persentase $(23,3 \%)$. Keenam, lima orang siswa yang mendapatkan nilai antara 60 sampai dengan 65 dengan persentase $(16,7 \%)$. Berdasarkan data tersebut diperoleh nilai rata-rata pretes yaitu 47,83. Dengan demikian dapat disimpulkan bahwa tingkat keterampilan menulis teks deskripsi siswa kelas VII SMP Negeri 1 Caringin sebelum perlakuan teknik brainwriting berada pada kategori kurang( 35-55) dengan persentase sebesar $70 \%$.

\section{Keterampilan Siswa Menulis Teks Deskripsi Setelah Menggunakan Teknik Brainwriting}

Keterampilan menulis teks deskripsi setelah pembelajaran menggunakan teknik brainwriting dengan jumlah sampel 30 siswa, diperoleh nilai terendah 75 , nilai tertinggi 90. Data lengkap nilai postes keterampilan siswa menulis teks deskripsi sebagai berikut. Pertama, 15 siswa mendapat nilai 75-78 dengan persentase $50 \%$. Kedua, 9 siswa mendapat nilai $79-82$ dengan persentase sebesar 30\%. Ketiga, 3 siswa mendapat nilai 83-86 dengan persentase sebesar $10 \%$. Keempat, 3 siswa mendapat nilai 86-90 dengan persentase $10 \%$. Berdasarkan data tersebut diperoleh rata-rata nilai postes sebesar 79,00. Dengan demikian dapat disimpulkan bahwa keterampilan siswa dalam menulis teks deskripsi setelah diberi perlakuan teknik brainwriting berada pada kategori baik (7585 ) dengan persentase sebesar $90 \%$.

\section{Pengaruh Teknik Brainwriting terhadap Keterampilan Menulis}

Teks Deskripsi Siswa kelas VII SMP Negeri 1 Caringin

Berdasarkan analisis data statistik dalam penelitian ini, keterampilan menulis teks deskripsi siswa sebelum menggunakan teknik brainwriting memperoleh nilai ratarata pretes yaitu 47,83 berada pada kategori kurang (35-55) dengan persentase sebesar $70 \%$. Sedangkan keterampilan menulis teks deskripsi siswa setelah menggunakan teknik brainwriting memperoleh nilai rata-rata postes yaitu 79,00 berada pada kategori baik (75-85) dengan persentase sebesar 90\%. Hal ini menunjukkan bahwa rata-rata nilai postes keterampilan menulis teks deskripsi siswa setelah menggunakan teknik brainwriting lebih tinggi daripada nilai ratarata pretes keterampilan menulis teks deskripsi siswa sebelum menggunakan teknik brainwriting. Berdasarkan hasil uji hipotesis yang dilakukan yaitu dengan uji-t diperoleh nilai $t_{\text {hitung }}$ sebesar 17,581, dan nilai $t_{\text {tabel }}$ sebesar 2,045 dengan derajat kebebasan (df) sebesar 29 dan tingkat signifikasi $95 \% \quad(0,05)$. Hasil analisis menunjukkan bahwa $t_{\text {hitung }}(17,581)>t_{\text {tabel }}$ $(2,045)$. Dengan demikian hipotesis nol ditolak dan hipotesis alternatif diterima. Berdasarkan hasil analisis data tersebut dapat disimpulkan bahwa teknik brainwriting berpengaruh secara signifikan terhadap keterampilan menulis teks deskripsi siswa kelas VII SMP Negeri 1 Caringin Kabupaten Sukabumi.

\section{SIMPULAN}

Berdasarkan hasil analisis data penelitian keterampilan menulis teks deskripsi siswa kelas VII SMP Negeri 1 Caringin Kabupaten Sukabumi diperoleh beberapa simpulan yaitu, pertama, keterampilan menulis teks deskripsi siswa kelas VII SMP Negeri 1 Caringin sebelum perlakuan teknik brainwriting diperoleh nilai rata-rata pretes sebesar 47,83, berada pada kategori kurang ( 35-55) dengan persentase sebesar $70 \%$. Kedua, keterampilan siswa dalam menulis teks deskripsi setelah diberi perlakuan teknik brainwriting dipeoleh nilai rata-rata postes sebesar 79,00, berada pada kategori baik (75-85) dengan persentase sebesar 90\%. Ketiga, teknik brainwriting berpengaruh secara signifikan terhadap keterampilan menulis teks deskripsi siswa kelas VII SMP Negeri 1 Caringin Kabupaten Sukabumi. Hal ini ditunjukkan dengan hasil penelitian yang dibuktikan dengan $t_{\text {hitung }}(17,581)>t_{\text {tabel }}(2,045)$, sehingga hipotesis nol ditolak dan hipotesis alternatif diterima. 


\section{DAFTAR PUSTAKA}

Arikunto, S. (2014). Prosedur Penelitian: Suatu Pendekatan Praktik (Cetakan ke-15). Jakarta: Rineka Cipta.

Brokop, Flo dan Bill Persal. (2009). Writing Strategies for Learner who are Deaf. Edmonton:NorQuest College.

Chaer, A. (2014). Linguistik Umum (Edisi Revisi). Jakarta: Rineka Cipta.

Damai, et al.(2017). Pembelajaran Bahasa Indonesia untuk SD (Pendekatan dan Teknis). Jakarta:Media Maxima.

Kosasih, E. Dan Kurniawan, E. (2018). Jenis-Jenis Teks Fungsi, Struktur, dan Kaidah Kebahasaan. Bandung:Yrama Widya.

Paulus and Nijstad. (2003). Group Creatitivity. New York: Oxford University Press.

Sugiyono. (2017). Metode Penelitian Kuantitatif, Kualitatif, dan $R \& D$. Bandung:Alfabet. 